\title{
REGULARITIES OF PROTEOLYSIS OF PACKED LIVESTOCK RED BLOOD CELLS
}

\author{
Olga V. Kriger
}

Kemerovo Institute of Food Science and Technology (University), Stroiteley Boul. 47, Kemerovo, 650056 Russian Federation

Received April 27, 2016;

e-mail: olgakriger58@mail.ru

Accepted in revised form June 09, 2016;

Published June 30, 2016

\begin{abstract}
Actual methods for anti-anemic preparation producing are characterized by a number of weak points: significant hemoglobin losses during hemolysis; difficulties in achieving a high hemoglobin purity level; expensive and complex instrumentation etc. A promising direction of this research is a study of a possibility to get iron-containing mass from meat-producing animals' blood through hydrolysis with acetic and citric acids. The author studies a correlation dependence of acid concentration on amine nitrogen mass fraction, heme iron, hydrolysis level. For packed pork blood cells, the highest amine nitrogen values are typical under the use of acetic and citric acids with mass fraction of $10 \%$, which corresponds to $357 \mathrm{mg} / 100 \mathrm{~cm}^{3}$ under the duration of 10 hours for citric acid and $305 \mathrm{mg} / 100 \mathrm{~cm}^{3}$ under the duration of 8 hours for acetic acid. Under packed cattle blood cells hydrolysis, the highest amine nitrogen values are typical under the use of $10 \%$ citric acid solution and $10 \%$ acetic acid solution, which corresponds to $268 \mathrm{mg} / 100 \mathrm{~cm}^{3}$ и $229 \mathrm{mg} / 100 \mathrm{~cm}^{3}$ respectively. Iron yield has positive increasing dynamics. 11-12 hour hydrolysis is relatively stable, the changes in iron content are insignificant, which means that hydrolysis time increase makes no sense. Favourable conditions for hydrolysis are: mass fraction of citric acid $-10 \%$, mass fraction of citric acid $-5 \%$, mass fraction of acetic acid - $10 \%$, temperature $-50 \pm 1{ }^{\circ} \mathrm{C}$, process time -12 hours.
\end{abstract}

Keywords: proteolysis, packed red blood cells, heme iron

\section{INTRODUCTION}

The tendencies in the field of industrial food production are connected with the creation of functional food assortment contributing to maintaining and correcting health upon condition of day-to-day consumption due to regulatory and normalizing effect on particular organs and their functions or a whole body itself $[1,2]$.

Secondary derivative products of agricultural raw materials have a special place here. They are a source of biopolymers and their essential structural units indispensable amino acids, polyunsaturated fatty acids, organic iron, and other macro- and micronutrients. They play an important role in enriching the foodstuff, both traditional assortment and new products including simulated mass-market food products, that can have a regenerating and stabilizing effect on an internal environment of a human body [2,3].

There is a way that is related to the technology of obtaining biologically active compounds from raw animal material, more specifically, to the industrial processes of recovering iron protein hemoglobin from farm animals' blood [4].

Hemoglobin of different purity levels can be used as a concentrated source of biologically available iron in the process of food production, oral nutritional supplement (ONS), fodder, veterinary and medicinal drugs in order to prevent and to treat iron-deficiency conditions of humans and animals [5].
However, actual methods for anti-anemic preparation producing are characterized by a number of weak points: significant hemoglobin losses during hemolysis; difficulties in achieving high hemoglobin purity level and, consequently, high iron availability; expensive and complex instrumentation; multiple-stage character. All these drawbacks lead to a high cost of hemoglobin and, subsequently, final functional antianemic products. A promising direction of this research is a study of a possibility to get iron-containing mass from meat-producing animals' blood through hydrolysis [6-8].

The main advantage of employing red blood cells hydrolysis for iron-containing mass before employing hemolysis is a high level of heme iron digestibility as compared to hemoglobin-based preparations. Besides, iron-containing preparations produced through hydrolysis of farm animals' erythrocyte proteins comprise highly digestible amino acids $[9,10]$.

Effective way of blood hydrolysis for producing iron-containing supplement is acidic hydrolysis. However, under these conditions there are amine nitrogen potential losses may be from 32 to $42 \%$ on different stages of technical process (hydrolysis, neutralization, breaking, purification).

Therefore, it is necessary to pick hydrolysis conditions providing high level of farm animals' packed red cells hydrolysis and conducing free heme iron and amine nitrogen yield.

\footnotetext{
Please cite this article in press as: Kriger O.V. Regularities of proteolysis of packed livestock red blood cells. Science Evolution, 2016, vol. 1, no. 1, pp. 85-91.

Copyright (C) 2016, KemSU. This is an open access article distributed under the terms of the Creative Commons Attribution 4.0 International License (http://creativecommons.org/licenses/by/4.0/), allowing third parties to copy and redistribute the material in any medium or format and to remix, transform, and build upon the material for any purpose, even commercially, provided the original work is properly cited and states its license. This article is published with open access at http://science-evolution.ru/.
} 


\section{OBJECTS AND METHODS OF STUDY}

Edible acids (acetic and citric) were used as hydrolyzing acids for hydrolysis of pork and cattle packed red cells.

For hydrolysis, we used packed red cells produced during stabilized blood separation under the following parameters: process time was 360 seconds for pork blood and 330 second for cattle blood. 2000 units was taken as an optimum separation factor for both kinds of raw materials.

Conventional, standard and innovative methods were used to perform the present research. Theoretical and experimental studies were performed in the light of modern methodology of complex phenomenon research through conventional and innovative methods of biochemical, physical-chemical, structuralmechanical analysis using the latest advances in science and technology.
Amine nitrogen was determined through formol titration, and total nitrogen - through Kjeldahl method. The degree of hydrolysis was determined as a ratio of amine nitrogen to total nitrogen. Heme iron content was determined in accordance with all-Union State Standard GOST-26928-86. Nutrition products. Method for iron determination.

\section{RESULTS AND DISCUSSION}

Final hydrolysis product represents a mixture of free heme iron and peptides with different molecular weight. There are no neutralization and filtration stages. It helps to prevent amine nitrogen and heme iron losses.

For hydrolysis we used 1\%-, 5\%- and 10\%solutions of acetic and citric acids at a temperature of $50 \pm 1{ }^{\circ} \mathrm{C}$. Acid solution was put in quantity of $10 \%$ to a packed red cells volume. The dependence of amine nitrogen mass fraction on hydrolysis process time, kind and concentration of the acid is presented in Fig. 1-4.

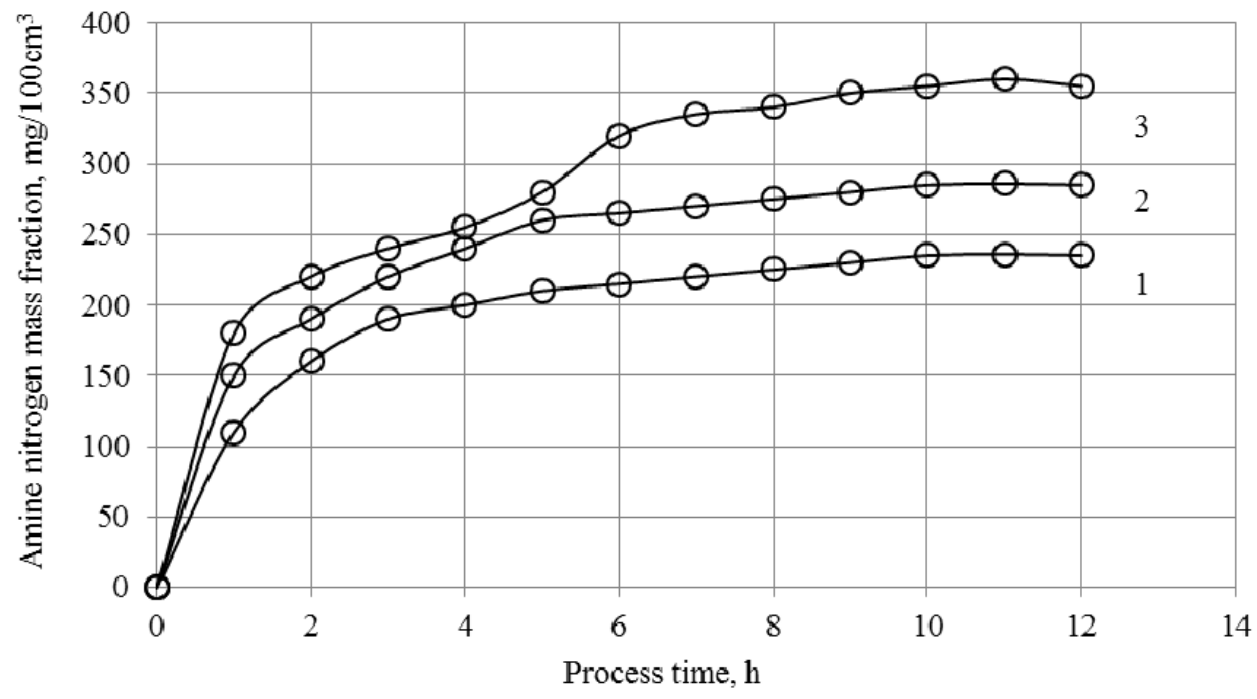

Fig. 1. The dynamics of amine nitrogen yield under packed pork blood cells hydrolysis with citric acid: 1 - 1\%-solution; 2 - 5\%- solution; 3 - 10\%- solution.

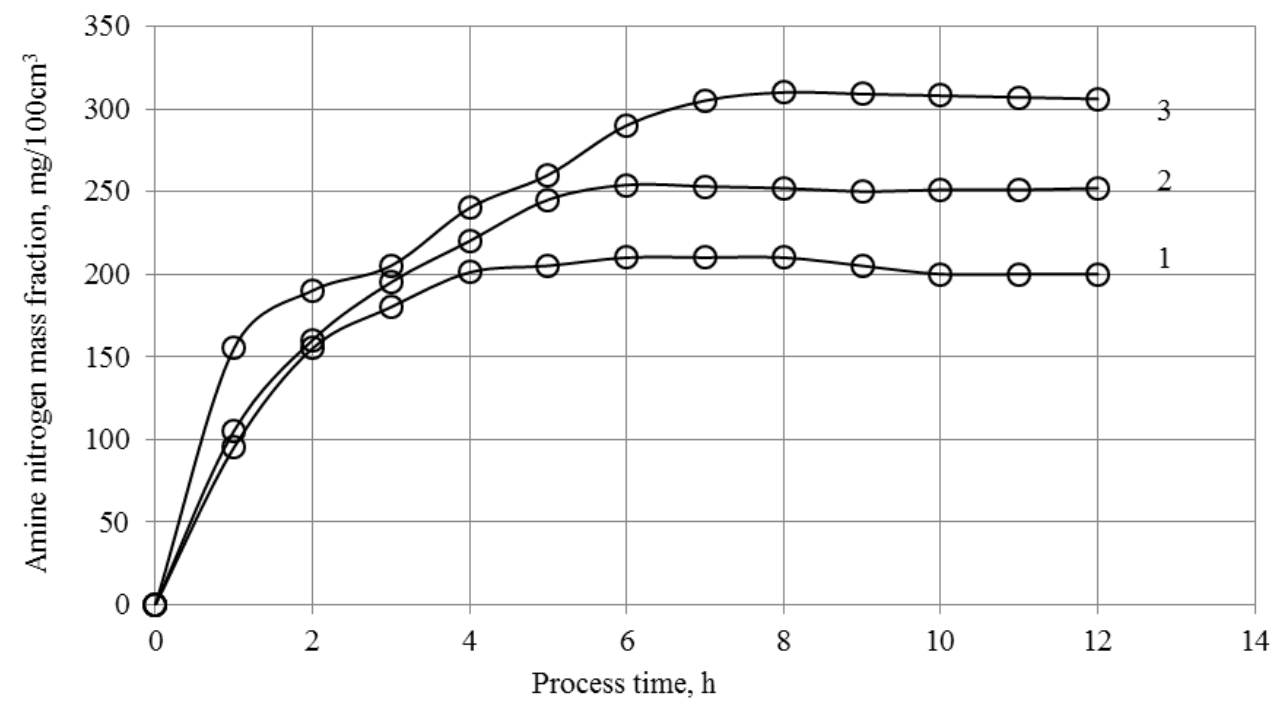

Fig. 2. The dynamics of amine nitrogen yield under packed pork blood cells hydrolysis with acetic acid: 1 - 1\%solution; 2 - 5\%- solution; 3 - 10\%- solution. 


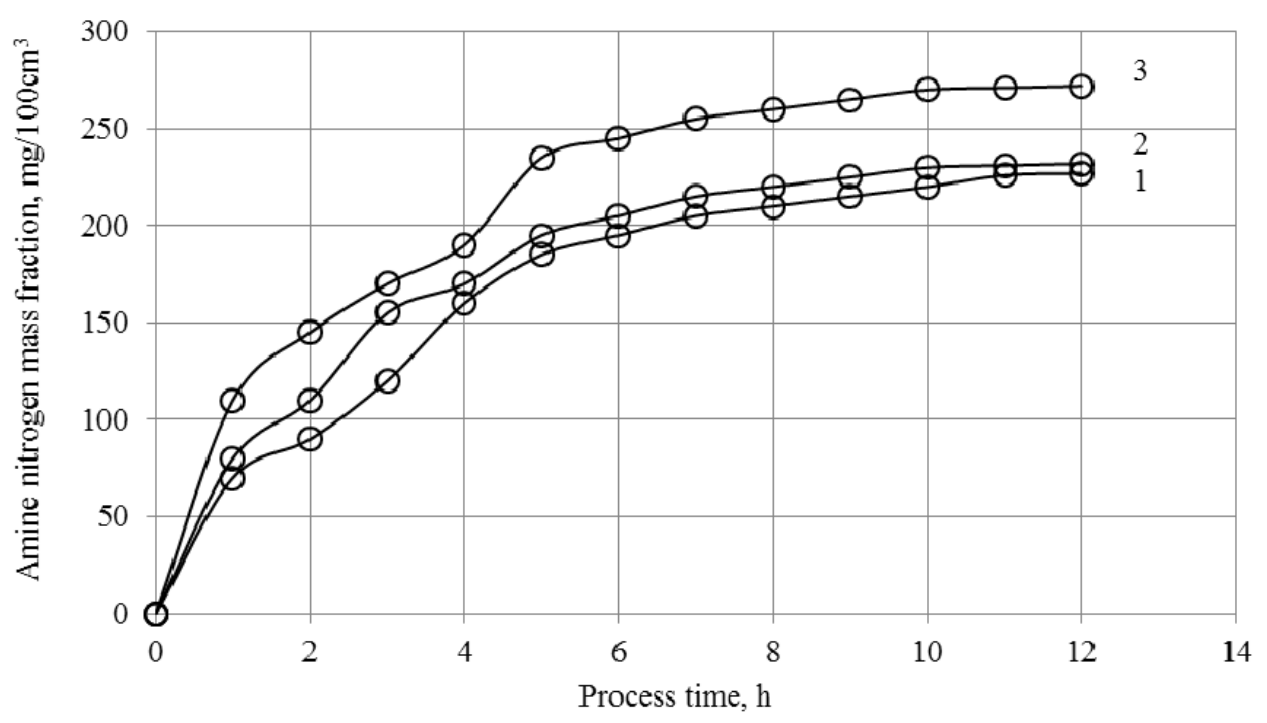

Fig. 3. The dynamics of amine nitrogen yield under packed cattle blood cells hydrolysis with citric acid: $1-1 \%$ solution; 2 - 5\%- solution; 3 - 10\%- solution.



Fig. 4. The dynamics of amine nitrogen yield under packed cattle blood cells hydrolysis with acetic acid: $1-1 \%$ solution; $2-5 \%$ - solution; $3-10 \%$ - solution.

Having analyzed pictures 1-4 data, we have come to the following conclusions. The dependences of amine nitrogen mass fraction on hydrolysis process time, kind and concentration of used acid have general nature for packed red cells of blood of two animals.

The content of amine nitrogen in the process of packed red cells hydrolysis is marked by two specific zones: a zone of constant amine nitrogen growth during 8-10 hours under hydrolysis with citric acid and 5-6 hours under hydrolysis with acetic acid. The second zone is a zone of a relatively stable amine nitrogen content during 2 hours under hydrolysis with citric acid and 5-6 under hydrolysis with acetic acid.

However, there are differences in quantitative content of amine nitrogen depending on a kind of an animal. For packed pork blood cells, the highest amine nitrogen values are typical under the use of acetic and citric acids with mass fraction of $10 \%$, which corresponds to $357 \mathrm{mg} / 100 \mathrm{~cm}^{3}$ under the duration of 10 hours for citric acid and $305 \mathrm{mg} / 100 \mathrm{~cm}^{3}$ under the duration of 8 hours for acetic acid.

There is also high yield of amine nitrogen under packed pork blood cells hydrolysis with $5 \%$ citric acid solution. Amine nitrogen mass fraction after 10 hours hydrolysis is $290 \mathrm{mg} / 100 \mathrm{~cm}^{3}$. Then amine nitrogen growth rates edge down, the changes of amine nitrogen are insignificant, which means that hydrolysis is nearly over. That is why hydrolysis lasting more than 12 hours is pointless. Results are considered ineffective under hydrolysis with $1 \%$ citric acid solution and 5\% acetic acid solution.

Under packed cattle blood cells hydrolysis, there is a great jump corresponding to process duration of 5 hours, then amine nitrogen mass fraction increases 
insignificantly. The highest amine nitrogen values are typical under the use of $10 \%$ citric acid solution and $10 \%$ acetic acid solution, which corresponds to $230 \mathrm{mg} / 100 \mathrm{~cm}^{3}$ и $200 \mathrm{mg} / 100 \mathrm{~cm}^{3}$ respectively.

At the end of hydrolysis amine nitrogen mass fraction is $268 \mathrm{mg} / 100 \mathrm{~cm}^{3}$ for citric acid (the growth of amine nitrogen is $14.1 \%$ ) and $229 \mathrm{mg} / 100 \mathrm{~cm}^{3}$ for acetic acid (the growth of amine nitrogen is $12.6 \%$ ). As can be seen from the above, packed cattle blood cells hydrolysis makes sense with citric and acetic acid with mass fraction of $10 \%$. The process time should not go beyond 12 hours.

Besides, we have measured free heme iron quantity in the process of hydrolysis of packed pork and cattle blood cells with different variants of citric and acetic acid (Table 1-2).

Table 1. Heme iron mass fraction under packed pork blood cells hydrolysis

\begin{tabular}{|c|c|c|c|c|c|c|}
\hline \multirow{2}{*}{$\begin{array}{c}\text { Process } \\
\text { time, } \mathrm{h}\end{array}$} & \begin{tabular}{c} 
Free heme iron content, \% to hydrolysate mass \\
\cline { 2 - 7 } \\
\cline { 2 - 7 } \\
fraction of 1\%
\end{tabular} & $\begin{array}{c}\text { citric acid } \\
\text { mass fraction } \\
\text { of 5\% }\end{array}$ & $\begin{array}{c}\text { citric acid } \\
\text { mass fraction } \\
\text { of } 10 \%\end{array}$ & $\begin{array}{c}\text { acetic acid } \\
\text { mass fraction } \\
\text { of } 1 \%\end{array}$ & $\begin{array}{c}\text { acetic acid } \\
\text { mass fraction } \\
\text { of } 5 \%\end{array}$ & $\begin{array}{c}\text { acetic acid } \\
\text { mass fraction } \\
\text { of } 10 \%\end{array}$ \\
\hline 1 & $0.05 \pm 0.02$ & $0.07 \pm 0.02$ & $0.10 \pm 0.07$ & $0.04 \pm 0.02$ & $0.05 \pm 0.02$ & $0.07 \pm 0.02$ \\
\hline 3 & $0.09 \pm 0.02$ & $0.11 \pm 0.07$ & $0.14 \pm 0.07$ & $0.08 \pm 0.07$ & $0.09 \pm 0.07$ & $0.11 \pm 0.07$ \\
\hline 5 & $0.15 \pm 0.07$ & $0.17 \pm 0.07$ & $0.20 \pm 0.11$ & $0.14 \pm 0.07$ & $0.15 \pm 0.07$ & $0.17 \pm 0.07$ \\
\hline 7 & $0.22 \pm 0.11$ & $0.26 \pm 0.11$ & $0.29 \pm 0.11$ & $0.20 \pm 0.11$ & $0.22 \pm 0.11$ & $0.24 \pm 0.11$ \\
\hline 9 & $0.26 \pm 0.11$ & $0.30 \pm 0.15$ & $0.33 \pm 0.15$ & $0.24 \pm 0.11$ & $0.24 \pm 0.11$ & $0.26 \pm 0.11$ \\
\hline 11 & $0.29 \pm 0.11$ & $0.33 \pm 0.15$ & $0.36 \pm 0.15$ & $0.27 \pm 0.15$ & $0.28 \pm 0.11$ & $0.30 \pm 0.15$ \\
\hline 12 & $0.29 \pm 0.11$ & $0.33 \pm 0.15$ & $0.35 \pm 0.15$ & $0.27 \pm 0.15$ & $0.28 \pm 0.11$ & $0.30 \pm 0.15$ \\
\hline
\end{tabular}

Table 2. Heme iron mass fraction under packed cattle blood cells hydrolysis

\begin{tabular}{|c|c|c|c|c|c|c|}
\hline \multirow{2}{*}{$\begin{array}{c}\text { Process } \\
\text { time, } \mathrm{h}\end{array}$} & $\begin{array}{c}\text { Free heme iron content, \% to hydrolysate mass } \\
\text { citric acid mass } \\
\text { fraction of 1\% }\end{array}$ & $\begin{array}{c}\text { citric acid } \\
\text { mass fraction } \\
\text { of } 5 \%\end{array}$ & $\begin{array}{c}\text { citric acid } \\
\text { mass fraction } \\
\text { of } 10 \%\end{array}$ & $\begin{array}{c}\text { acetic acid } \\
\text { mass fraction } \\
\text { of } 1 \%\end{array}$ & $\begin{array}{c}\text { acetic acid } \\
\text { mass fraction } \\
\text { of } 5 \%\end{array}$ & $\begin{array}{c}\text { acetic acid } \\
\text { mass fraction } \\
\text { of } 10 \%\end{array}$ \\
\hline 1 & $0.03 \pm 0.01$ & $0.05 \pm 0.02$ & $0.08 \pm 0.02$ & $0.02 \pm 0.02$ & $0.03 \pm 0.02$ & $0.05 \pm 0.02$ \\
\hline 3 & $0.07 \pm 0.01$ & $0.09 \pm 0.02$ & $0.12 \pm 0.07$ & $0.06 \pm 0.02$ & $0.07 \pm 0.02$ & $0.09 \pm 0.02$ \\
\hline 5 & $0.11 \pm 0.01$ & $0.13 \pm 0.07$ & $0.16 \pm 0.07$ & $0.10 \pm 0.07$ & $0.11 \pm 0.07$ & $0.13 \pm 0.07$ \\
\hline 7 & $0.15 \pm 0.01$ & $0.19 \pm 0.07$ & $0.22 \pm 0.07$ & $0.13 \pm 0.07$ & $0.15 \pm 0.07$ & $0.17 \pm 0.07$ \\
\hline 9 & $0.19 \pm 0.01$ & $0.23 \pm 0.11$ & $0.26 \pm 0.07$ & $0.17 \pm 0.07$ & $0.17 \pm 0.07$ & $0.19 \pm 0.07$ \\
\hline 11 & $0.24 \pm 0.01$ & $0.28 \pm 0.11$ & $0.30 \pm 0.15$ & $0.22 \pm 0.11$ & $0.23 \pm 0.11$ & $0.25 \pm 0.11$ \\
\hline 12 & $0.25 \pm 0.01$ & $0.29 \pm 0.11$ & $0.31 \pm 0.15$ & $0.23 \pm 0.11$ & $0.24 \pm 0.11$ & $0.26 \pm 0.11$ \\
\hline
\end{tabular}

Iron quantity increases during 12 hours under all kinds of hydrolysis. However, it is necessary to say that the changes in iron content are insignificant up to the end of the process, which means that hydrolysis time increase by more than 12 hours makes no sense.

Under packed pork blood cells hydrolysis, the maximum iron quantity is observable upon use of $5 \%$ citric acid solution, iron content is $0.33 \pm 0.15 \%, 10 \%$ citric acid solution, iron content is $0.35 \pm 0.15 \%$, and $10 \%$ acetic acid solution, iron content is $0.30 \pm 0.15 \%$.

Under packed cattle blood cells hydrolysis, the maximum iron quantity is observable upon use of citric and acetic acid with mass fraction of $10 \%$ and citric acid with mass fraction of $5 \%$. Iron content is $0.31 \pm$ $0.15 \% ; 0,26 \pm 0.11 \% ; 0.29 \pm 0.11 \%$ respectively.

To make an optimum temperature choice, we have performed an experiment using the best options of acids: $10 \%$ citric acid solution, $5 \%$ citric acid solution and $10 \%$ acetic acid solution. The chosen temperature conditions are $45 \pm 1{ }^{\circ} \mathrm{C}, 50 \pm 1{ }^{\circ} \mathrm{C}$ и $55 \pm 1^{\circ} \mathrm{C}$. The efficiency of the process have been controlled in accordance with the level of packed red cell hydrolysis.

The dependences of packed red cell hydrolysis levels on hydrolysis process time are presented in Fig. 5 and 6.

Under packed pork blood cell hydrolysis, the highest hydrolysis level is $29.0 \%$ at the temperature of $45 \pm 1^{\circ} \mathrm{C}$ (Fig. 5, a) after 10 hours of hydrolysis with citric acid with mass fraction of $10 \%$. For acetic acid with mass fraction of $10 \%$ and citric acid with mass fraction of $5 \%$, the level of hydrolysis is $26.5 \%$ after the same period of time. During the following 2 hours the level of hydrolysis does not change for all options.

Under packed pork blood cell hydrolysis, the regularities of the whole process at the temperature of $50 \pm 1^{\circ}$ (Fig. 5, b) is the same as at the temperature of $45 \pm 1^{\circ} \mathrm{C}$. Tentatively, we can mark 2 periods. The first one is the period of the constant hydrolysis level increase. The second period is a stable period of hydrolysis level.

Under hydrolysis with citric acid with mass fraction of $5 \%$, hydrolysis level increase is observable during 
10 hours, the second period is the following 2 hours. The highest hydrolysis level value is $29.8 \%$.

Under hydrolysis with acetic acid with mass fraction of $10 \%$, the first period lasts 10 hours, the second one the following 2 hours. Hydrolysis level is $27.0 \%$.

Under hydrolysis with citric acid with mass fraction of $10 \%$, the period of hydrolysis level increase lasts 9 hours, the second period -3 hours. The highest hydrolysis level is $31.8 \%$.

Under packed pork blood cell hydrolysis at the temperature of $55 \pm 1^{\circ} \mathrm{C}$ (Fig. 5, c) the differences from hydrolysis at a temperature of $50 \pm 1{ }^{\circ} \mathrm{C}$ are insignificant in values. Hydrolysis with citric acid with mass fraction of $5 \%$ is performed up to the moment when hydrolysis level is $30.2 \%$. The period of hydrolysis level increase is 10 hours.

Under hydrolysis with acetic acid with mass fraction of $10 \%$, hydrolysis level increases up to $27.9 \%$ during 10 hours. During the last 2 hours the level does not change. Hydrolysis with citric acid with mass fraction of $10 \%$ leads to the hydrolysis level of $32.3 \%$ during 9 hours. The second period lasts the following 3 hours and does not lead to hydrolysis level increase.



(a)

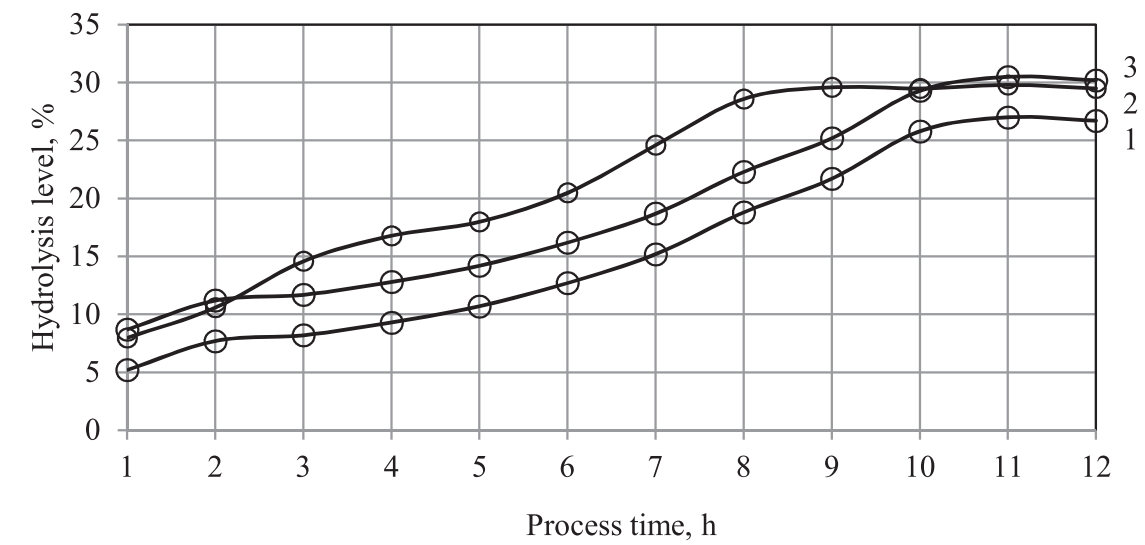

(b)



(c)

Fig. 5. The influence of process time on packed pork blood cell hydrolysis depending on the temperature: (a) $45 \pm 1{ }^{\circ} \mathrm{C}$; (b) $50 \pm 1{ }^{\circ} \mathrm{C}$; (c) $55 \pm 1{ }^{\circ} \mathrm{C} ; 1-5 \%$ citric acid solution; $2-10 \%$ acetic acid solution; $3-10 \%$ citric acid solution. 
Under packed cattle blood cell hydrolysis at the temperature of $45 \pm 1{ }^{\circ} \mathrm{C}$ (Fig. 6, a), the highest hydrolysis level is achieved due to the use of citric acid with mass fraction of $10 \%$ and goes to the level of $30.3 \%$. For acetic acid with mass fraction of $10 \%$ and citric acid with mass fraction of $5 \%$, this value is $28.0 \%$. These values are achieved after 10 hours of hydrolysis and are characterized by fixed values during the following 2 hours.

Under packed cattle blood cell hydrolysis at the temperature of $50 \pm 1^{\circ} \mathrm{C}$ (Fig. 6, b), the dependences of hydrolysis level have the same nature as hydrolysis at the temperature of $45 \pm 1^{\circ} \mathrm{C}$.

Under hydrolysis with citric acid with mass fraction of $5 \%$, the highest hydrolysis level is $29.8 \%$. This value is achieved after 11 hours. Under hydrolysis with citric acid with mass fraction of $10 \%$, the period of hydrolysis level increase lasts 9 hours. The second period lasts 3 hours. The highest hydrolysis level value is $30.5 \%$.

Packed cattle blood cell hydrolysis at the temperature of $55 \pm 1^{\circ} \mathrm{C}$ (Fig. 6, c) proceeds similar to packed pork blood cell hydrolysis at the same temperature. Under hydrolysis with citric acid with mass fraction of $5 \%$, the period of constant hydrolysis level increase is 9 hours; the second period lasts the following 3 hours. The highest hydrolysis level value is $30.2 \%$. The use of acetic acid with mass fraction of $10 \%$ helps to achieve hydrolysis level value of $27.5 \%$.

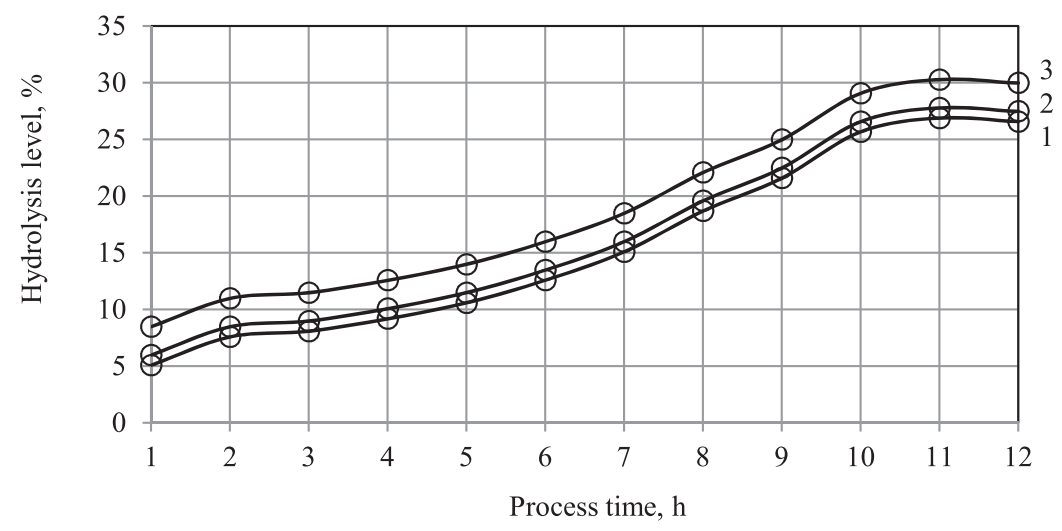

(a)

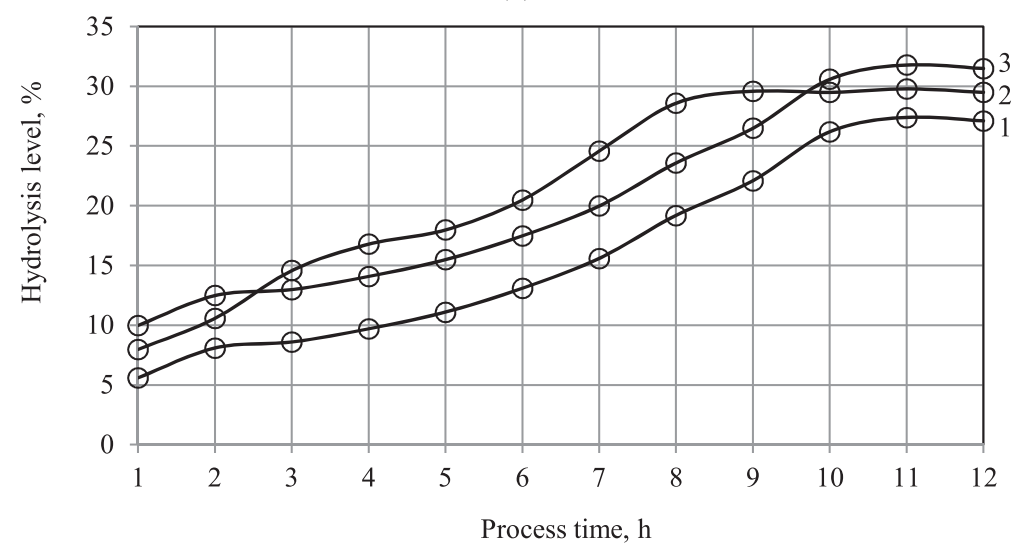

(b)

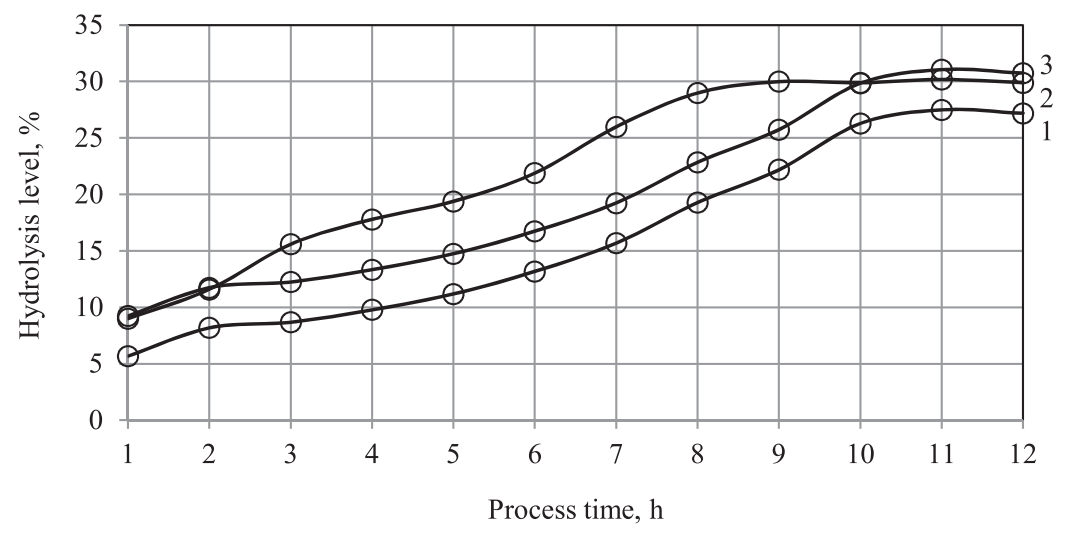

(c)

Fig. 6. The influence of process time on packed cattle blood cell hydrolysis depending on the temperature: (a) $45 \pm 1{ }^{\circ} \mathrm{C}$; (b) $50 \pm 1{ }^{\circ} \mathrm{C}$; (c) $55 \pm 1{ }^{\circ} \mathrm{C} ; 1-5 \%$ citric acid solution; $2-10 \%$ acetic acid solution; $3-10 \%$ citric acid solution. 
Hydrolysis with citric acid with mass fraction of $10 \%$ is characterized by 2 periods. The first one lasts 9 hours, the second one -3 . The highest hydrolysis level value is $31.0 \%$.

All experimental data received show that hydrolysis level depends on the temperature of the process. Still, the difference of the levels is no more than $2 \%$ at the temperatures of $50 \pm 1^{\circ} \mathrm{C}$ and $55 \pm 1^{\circ} \mathrm{C}$. Consequently, the temperature of $50 \pm 1{ }^{\circ} \mathrm{C}$ is optimal for packed pork and cattle blood cell hydrolysis.

Here are some conclusions of the research on the influence of hydrolysis parameters on amine nitrogen yield, free heme iron content and hydrolysis level. The following acids are suitable for packed pork and cattle blood cell hydrolysis: citric acid with mass fraction of $5 \%$, citric acid with mass fraction of $10 \%$, acetic acid with mass fraction of $10 \%$. Each of the variants has a positive effect of hydrolysis.
After hydrolysis is over, the resulted substance in all three cases is thick and has slightly sour flavour. For citric acid with mass fraction of $5 \%$, the liquid is brown with red shade; for citric acid with mass fraction of $10 \%-$ chocolate brown. For acetic acid with mass fraction of $10 \%$, hydrolysate has dark chocolate brown colour.

\section{CONCLUSION}

As can be seen from the above, the present research concerns the parameters of packed pork and cattle blood cell acid hydrolysis with the use of citric and acetic acids.

The study of dynamics of amine nitrogene and free heme iron storage, hydrolysis level and molecular-mass peptide distribution in hydrolysates reveals that hydrolysis is rational to perform with 10 citric acid solution during 12 hours at the temperature of $50 \pm 1^{\circ} \mathrm{C}$.

\section{REFERENCES}

1. Kochetkova, A.A., Tuzhilin V.I. Funktsional'nye pishchevye produkty: nekotorye tekhnologicheskie podrobnosti v obshchem voprose xFunctional foods: some technological details in general]. Pishchevaya promyshlennost' [Food Industry], 2003, no. 5, pp. 25-26.

2. Spirichev V.B., Shatnyuk L.K., Bol'shakov O.V. et al. Korrektsiya defitsita mikronutrientov v Rossii - opyt i perspektivy [The correction of micronutrient deficiencies in Russia. Experience and Prospects]. Pishchevaya promyshlennost' [Food Industry], 2000, no. 4, pp. 57-59.

3. Ladodo K.S., Sazhinov G.Yu. Spetsializirovannye produkty pitaniya dlya detey s razlichnoy patologiey [Specialized food for the children with different pathologies]. Moscow, 2000. 200 p.

4. Lyudvigovich L.S., Lyublinskaya I.N. Sposob kompleksnoy pererabotki krovi sel'skokhozyaystvennykh zhivotnykh dlya polucheniya biologicheski aktivnogo veshchestva s protivoanemicheskimi svoystvami na osnove gemoglobina, biologicheski aktivnoe veshchestvo s protivoanemicheskimi svoystvami (varianty) i produkt ego soderzhashchiy (varianty) [The method of complex processing of the blood of farm animals for the production of biologically active substances with antianemic properties based on hemoglobin, the biologically active substance with antianemic properties (options) and the product containing it (options)]. Patent RF, no. 2004106009 / 13, 02.03.2004.

5. Poznyakovskii, V.M. Gigienicheskie osnovy pitaniya, kachestvo i bezopasnost' pishchevykh produktov [Hygienic bases of food quality and food safety]. Novosibirsk: Sib. univ. Publishing House, 2007. 455 p.

6. Sizenko, E.I. Strategiya nauchnogo obespecheniya razvitiya konkurentosposobnogo proizvodstva otechestvennykh produktov pitaniya [The strategy of scientific support for the development of a competitive domestic production of food]. Khranenie $i$ pererabotka sel'khozsyr'ya [Storage and processing of primary produce], 2006, no. 1, pp. 7-9.

7. Spirichev V.B., Shatnyuk L.N. Biologicheski aktivnye komponenty (vitaminy, makro- i mikroelementy) v pishche XXI veka [Biologically active ingredients (vitamins, macro- and microelements) in the diet of XXI century]. Pishchevye ingredienty XXI veka: sbornik dokladov III Mezhdunar. foruma [Food Ingredients of the XXI century: a collection of III International forum]. Moscow, 2002, pp. 11-17.

8. Tutel'yan V.A. Mediko-biologicheskie trebovaniya k kachestvu i bezopasnosti spetsializirovannykh produktov dlya detskogo pitaniya [Medical and biological requirements for the quality and safety of specialized products for baby food]. Pishchevaya promyshlennost' [Food Industry], 1996, no. $9.13 \mathrm{p}$.

9. Ustinova A.V., Timoshenko N.V. Myasnye produkty dlya detskogo pitaniya [Meat products for baby food]. Moscow: Institute of Meat Industry, 1997. 252 p.

10. Izgarishev A.V., Kriger O.V., Prosekov A.Y., Babich O.O., Dushlyuk L.S. Innovative Approach to Fabrication of Blood Product of Farm Animals Intended for Prevention of Iron Deficiency. World Applied Sciences Journal, 2013, no. 23, no. 4, pp. 532-540.

\section{Olga V. Kriger}

Cand.Sci.(Eng.), Associate Professor, Professor of the Department of Bionanotechnology, Kemerovo Institute of Food Science and Technology (University), Kemerovo, Russian Federation. 